\title{
FROM GOLDSMITHS TO MODERN BANKING A Frank Look at the Money-Creation Process and its Relevance to Islamic Banking
}

\author{
Yusuf Jha*
}

\begin{abstract}
This paper discusses the role interest has played in the modern financial system, highlighting the money creation process in particular and the key questions that arise within Islamic Finance as a result. The paper contends that the legalisation of interest built the foundations for much of our modern day financial architecture with the modus operandi of commercial banking being its central element. As a result, money today is mainly created as interest-bearing debt with a host of associated consequences. Among these are an artificial economy of scarcity, endemic debt pressure, constant inflation, wealth polarisation, an ever present risk of default, and the environmentally irreconcilable paradigm of perpetual growth. Consequentially the interest-based modern financial system has seemingly set the world on a path necessitating an incessant demand to privatise, commoditise, and monetise ever increasing amounts of the earth's resources, causing us to live in an age where finance ${ }^{1}$, energy ${ }^{2}$, health care $^{3}$, and the ecosystem ${ }^{4}$ are reportedly headed towards imminent collapse. The question for Islamic finance practitioners is whether their discipline as currently practiced is actually providing a solution towards tackling these crises, or whether it is instead normalising the problems within an "Islamic" framework.
\end{abstract}

\section{Introduction}

The history of modern banking can be traced back to the societal tolerance accorded to interest/usury in Western Europe in the seventeenth century and the effect on one group in particular, the goldsmiths. Goldsmiths were originally depositaries for gold or commodity money, who kept gold deposits safe from the public in return for receipts promising payments and redemption to the bearers of those receipts. In what was eventually to become the antecedent of today's financial system, sixteenth-century goldsmith bankers, upon discovering that their receipts had in fact become de facto currency and that the proportion of receipts redeemed was far less than those issued, subsequently began issuing and lending amounts exceeding the total amount of gold they actually kept.

Crucially, instead of printing receipts to spend on their own consumption, they chose instead to lend them (at interest), whereby they would still be in control of the newly created money, thus allowing them to destroy the money upon repayment (and keep the interest). The key to all of this was the interest, which they could keep as a valid profit. Thus we see that the newfound legality 
of interest was a key lever in promoting the goldsmiths to the fore as a class of the financial elite.

The pointer to their commercial success lay in the question as to where the interest would come from. As the goldsmiths' money came into existence as interest-bearing debt, the money to be repaid was always more than that which had existed. What this meant was that (unless the economy was perpetually growing) such interest could only be repaid at someone else's expense. The goldsmiths had thus instituted a zero-sum game in their own favour. This was arguably the greatest business idea ever invented. The business model of creating fictional money as interest-bearing debt, destroying the created money before subsequently keeping the interest, still exists today in what we have come to know as commercial banking, more aptly described as "institutionalised usury" (Rowbotham, 1998, 26).

\section{STEP 1: MAKING INTEREST PERMISSIBLE}

Whom: In early $16^{\text {th }}$ century, primarily Christian Reformists in Western Europe, such as Luther and Calvin
Effect: Social tolerance acquired for interest, new dichotomy between interest and usury

\section{STEP 2: BIRTH OF MODERN BANKING}

Whom: In 16th century, goldsmiths who kept gold deposits and issued receipts in exchange to be redeemed later
Effect: Birth of Modern Banking through money creation, lending at interest and then destroying money on payment

\section{STEP 3: CREATION OF FIRST CENTRAL BANK}

Whom: In 1694, banks in England lent King William \$1.2 million at interest to fight his War of Succession
Effect: Bankers nationalised the debt, forming in return the first independent central bank; gaining the right to print paper currency

Figure 1: Showing the key steps that resulted in modern banking, the "institutionalisation of interest"

Present day commercial banks employ a money creation process that is simpler still. Unlike the goldsmiths of old, most of modern money is created "ex nihilo" by simply making an accounting entry in a bank's ledger, i.e., by simply entering digits on a screen. 
Strange to believe but true, as former Harvard Business School lecturer and award winning author David. C. Korten notes, "When a loan is issued, the bank's accountant enters two numbers in the bank's accounting records: she records the borrower's promise to repay the loan as an asset, and the money the bank puts into the borrower's account as a liability... With the accountant's entries, the bank created new money from nothing in the amount of the loan principal and caused the amount of money in the economy as a whole to increase" $(2010,37)$. In similar fashion, Sir Mervyn King, the Governor of the Bank of England, says, "When banks extend loans to their customers, they create money by crediting their customers' accounts." ${ }^{\prime 5}$ Likewise, Martin Wolf, the chief economics editor for the Financial Times, says, "The essence of the contemporary monetary system is creation of money, out of nothing, by private banks' often foolish lending."

And this is only natural, for as Ryan-Collins and others $(2011,4)$ demonstrate, "Banks do not need to wait for a customer to deposit money before they can make a new loan to someone else. In fact, it is exactly the opposite; the making of a loan creates a new deposit in the customer's account."

But clearly this differs from what most people assume. Popular thought has always been that banks actually lend from money acquired, that they perform the function of financial intermediaries by taking money from savers and lending this money out to borrowers. The chairman of the Financial Services Authority (UK), Lord Adair Turner, articulately corrects this misconception: "The banking system can thus create credit and create spending power - a reality not well captured by many apparently common sense descriptions of the functions which banks perform... ; in fact they don't just allocate pre-existing savings, collectively they create both credit and the deposit money which appears to finance that credit."

Today due to the institutionalisation of interest and the advent of digital money, roughly 97 percent of modern money comes into existence as interestbearing debt; i.e., it "comes into being only when someone promises to pay back even more of it." ${ }^{\prime}$ As a result, it follows that either some of these loans must end up in default, or that the supply of money must continually grow. In practice, fiscal policy seems to be a balancing act between these two extremes. On the one hand, there is the need to continually grow so as to prevent the first option and on the other hand there is a cap on the alternative option, i.e., growing too much, for when money is created, "in amounts exceeding the ability of the economy to create new goods and services, the result is inflation" (Eisenstein, 2007, 269). Thus today the entire global economy is trapped in a trajectory of seeking "non-inflationary economic growth - an increase in the production of goods and services ... [and] the relentless conversion of life into money" (Eisenstein, 269). 


\section{How exactly does this happen?}

The key to understanding how banks create money is to recognise the different types of money in existence.

In essence, there are at present three types of money:

1. Cash - banknotes and coins.

2. Central bank reserves - reserves held by commercial banks at the Bank of England.

3. Commercial bank money - bank deposits created when commercial banks lend money, thereby crediting credit borrowers' deposit accounts.

While the state creates the first two types of money, the money that actually circulates in the general economy is only of types 1 and 3. Of these, physical cash generally accounts for less than 3 percent of the total stock of money in the economy. Commercial bank money (exclusively created by commercial banks), credit and coexistent deposits, makes up the remaining 97 percent of the money supply.

\section{What is commercial bank money?}

Perhaps the simplest way to explain commercial bank money is to recognise that the system allows an extension of a liability from a bank, effectively an IOU, as an accounting entry, to be treated as money.

As Ryan-Collins and others state, "An IOU from a friend is not acceptable at the tax office or in the local shop, an IOU from a bank most definitely is." (2011, 3) The result is that "banks create new money whenever they extend credit, buy existing assets or make payments on their own account, which mostly involves expanding their assets, and that their ability to do this is only very weakly linked to the amount of reserves they hold at the central bank" (3).

There is nothing controversial about this statement, for standard economic theory recognises this concept, as it is not uncommon to study the money multiplier effect in economic text books. In fact many Central Bank documents themselves usually state this; a Chicago Federal Reserve Bank paper explicitly states that the "actual process of money creation takes place primarily in banks" (Modern Money Mechanics, 1994, 3). Likewise a recent Bank of England paper says, "By far the largest role in creating broad money is played by the banking sector... When banks make loans they create additional deposits for those that have borrowed the money." In fact the definition of broad money itself is defined by the Deputy Governor for Financial Stability in the Bank of England as an accounting entry; Paul Tucker says, "[Banks] can lend simply by expanding the two sides of their balance sheet simultaneously, creating (broad) money." 10 All of these quotations and more ${ }^{11}$ testify to the fact that the creation of money 
in the UK and across the world has effectively been privatised in the hands of commercial banks. In other words commercial banks effectively create almost all of the money in the world as debt when they lend. This has a wide range of rarely discussed consequences and effects upon the economy and society, which this paper hopes to discuss. But before that we intend to focus on the money multiplier theory, which though instructive, is not entirely accurate.

\section{What is the money multiplier theory?}

The standard money multiplier theory states that the amount of money that can be created is limited by a centrally agreed reserve ratio, thus implying an implicit cap on or control of the amount of money created by the private banks. This theory is widely taught in economics and banking courses across the globe. Despite its wide acceptance, the theory has its limitations and may lead to wrong assumptions with regard to banking and the money creation process, something we will seek to clarify and discuss later.

In broad terms the theory argues that an agreed reserve ratio will control the amount of money that can be created. For example, a 10 percent reserve ratio will only allow for a 90 percent increase. This is because as a Chicago Federal Reserve document states, "Since only $\$ 10$ must be held against the new $\$ 100$ in deposits, $\$ 90$ is excess reserves and can give rise to $\$ 900$ of additional deposits" (Modern Money Mechanics, 16).

The figure below illustrates how this happens. Using an initial deposit of $\$ 100$ as an example, this figure shows how theoretically the various reserve requirements can lead to the different amounts of money creation.

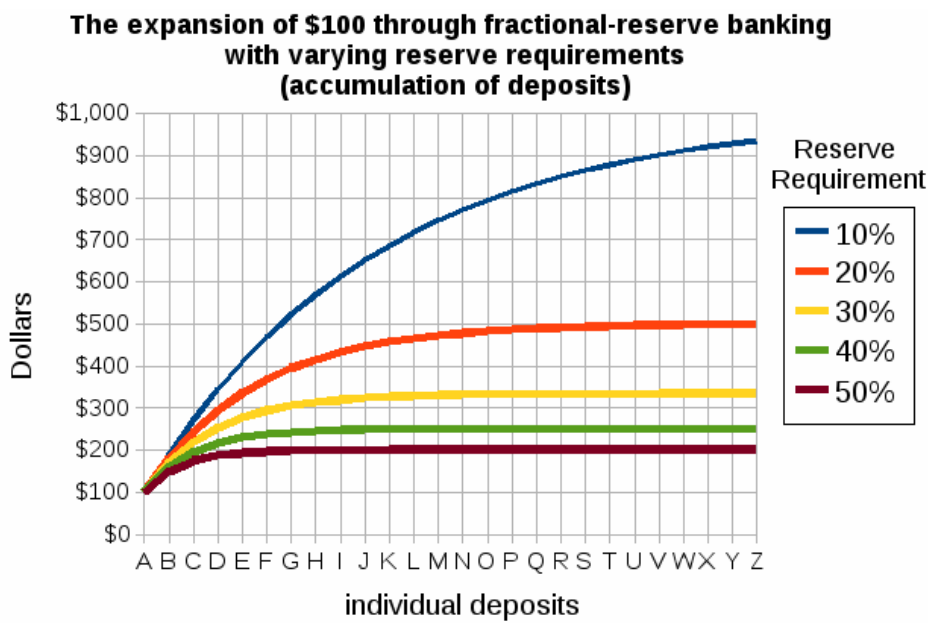

Figure 2: Showing monetary expansion with varying reserve ratios (Open Source) 
In order to further illustrate the money creation process, let us take a scenario whereby a bank receives a deposit of $£ 100,000$ in cash. As a result of using the principle of double entry book-keeping, both its assets and the total of its liabilities to its customers would rise by the same amount.

We then take a bank's liability-to-cash-reserve ratio as being 10:1. This would mean that the bank can now lend out 90 percent of whatever deposit it has received, thereby creating further deposits throughout the banking system in the process show below. The key to the money creation process is that this 90 percent is not taken from existing money (in this case $£ 100,000$ ), for if that were to happen, no extra money would be created. Rather, this money is created out of nothing, as mentioned, simply as an accounting entry (Korten, 37). This means that if each bank across an economy takes in a deposit and creates new loans to the degree of 90 percent of whatever deposit it had received (while keeping the existing money), then assuming the money circulates ad infinitum in a closed economy, we would have a scenario of money creation similar to the table below:

\begin{tabular}{|c|c|c|c|c|}
\hline $\begin{array}{c}\text { Bank Account } \\
\text { (in same of a } \\
\text { different bank) }\end{array}$ & Deposit in GBP & Loan in GBP & $\begin{array}{c}\text { Cash Reserve } \\
\text { Requirement }\end{array}$ & $\begin{array}{c}\text { Cash Reserves } \\
\text { in GBP }\end{array}$ \\
\hline $\mathbf{1}$ & 100,000 & 90,000 & $10 \%$ & 10,000 \\
\hline $\mathbf{2}$ & 90,000 & 81,000 & $10 \%$ & 9,000 \\
\hline $\mathbf{3}$ & 81,000 & 72,900 & $10 \%$ & 8,100 \\
\hline $\mathbf{4}$ & 72,900 & 65,610 & $10 \%$ & 7,290 \\
\hline $\mathbf{5}$ & 65,610 & 59,049 & $10 \%$ & 6,561 \\
\hline $\mathbf{6}$ & 59,049 & 53,144 & $10 \%$ & 5,905 \\
\hline $\mathbf{7}$ & 53,144 & 47,830 & $10 \%$ & 5,314 \\
\hline $\mathbf{8}$ & 47,830 & 43,047 & $10 \%$ & 4,783 \\
\hline $\mathbf{9}$ & 43,047 & 38,742 & $10 \%$ & 4,305 \\
\hline $\mathbf{1 0}$ & 38,742 & 34,868 & $10 \%$ & 3,874 \\
\hline $\mathbf{1 1}$ & 34,868 & 31,381 & $10 \%$ & 3,487 \\
\hline $\mathbf{1 2}$ & 31,381 & 28,243 & $10 \%$ & 3,138 \\
\hline $\mathbf{1 3}$ & 28,243 & 25,419 & $10 \%$ & 2,824 \\
\hline $\mathbf{1 4}$ & 25,419 & 22,877 & $10 \%$ & 2,542 \\
\hline $\mathbf{1 5}$ & 22,877 & 20,589 & $10 \%$ & 2,288 \\
\hline $\mathbf{1 6}$ & 20,589 & 18,530 & $10 \%$ & 2,059 \\
\hline $\mathbf{1 7}$ & 18,530 & 16,677 & $10 \%$ & 1,853 \\
\hline $\mathbf{1 8}$ & 16,677 & 15,009 & $10 \%$ & 1,668 \\
\hline $\mathbf{1 9}$ & 15,009 & 13,509 & $10 \%$ & 1,501 \\
\hline $\mathbf{2 0}$ & 13,509 & 12,158 & $10 \%$ & 1,351 \\
\hline$\cdot$ &. &. &. &. \\
\hline$\cdot$ &. &. &. &. \\
\hline $\mathbf{N}$ & $\cdot$ & $\cdot$ & $\mathbf{1 0} \%$ & $\mathbf{1 0 0 , 0 0 0}$ \\
\hline $\mathbf{N}$ & $\mathbf{1 , 0 0 0 , 0 0 0}$ & $\mathbf{9 0 0 , 0 0 0}$ & & \\
\hline
\end{tabular}

Figure 3: Showing monetary expansion in tabular format 
As the table above shows, with an initial $£ 100,000$ and a 10 percent reserve ratio, $£ 900,000$ can be created out of nothing. In effect, with a 10 percent reserve requirement, the banking system as a whole has the capacity to create 90 percent extra money based on the initial deposit.

In formulaic terms, the money multiplier is expressed as: $m=\frac{1}{R}$ Where $m$, the money multiplier is the inverse of the reserve requirement, $R$.

\section{Is the money multiplier theory entirely accurate?}

While the money multiplier as standard economic discourse recognises the fact that banks create money out of nothing from an initial deposit, it is still not entirely accurate. For inherent in the money multiplier theory is the assumption that central banks and reserve ratios actually control the money expansion process. This is not true, at least not in the case of most Western countries, with the UK being a prime example.

For the UK specifically, following deregulation in 1981 of domestic and international finance, banks choose their own reserve targets rather than have them determined by a balance sheet ratio of any kind. ${ }^{12}$ Such changes are in keeping with today's world of globalised capital flows and banking services which has seen a shift away from domestic regulation and ratios to an international regime of banking regulation with policy developed by the Basel Committee on Banking Supervision $^{13}$ (commonly referred to as the Basel Accord). With the Basel Committee itself being a private body of central banks and regulators linked to the Bank for International Settlement (BIS), the Basel Accord rules are not formally binding through any national regulators but instead are targets specified by multilateral regulatory authorities (such as the EU in Brussels) that pertain to the solvency assurance of banks (their capital adequacy specifically). While the recent banking crisis has demonstrated that previous Basel Accord ratios (I and II) have all been circumvented by the use of derivatives, off-balance sheet Special Purpose Vehicles (SPVs), and a range of innovative capital instruments, the latest round of revised Basel Accord rules (Basel III) already seems to indicate a similar direction with the introduction of perpetual Tier 1 capital notes. ${ }^{14}$ All of this has led several observers to consider the Basel committee itself to be strongly influenced by the goals of the largest banks in industrialised countries, which is a conflict of interest. The upshot is that with no local regulatory ratios and with global regulatory standards such as the Basel Accord (I, II and recently $\mathrm{III}^{15}$ ) being both loosely applied and easily circumvented, there are effectively no limits on credit expansion for banks and no limits barring the possibility of the banks not receiving the newly created credit back. Banks would then have to take the losses from the defaulted loans on their balance sheets, which explains their reluctance to lend in difficult times. 
In short, it seems banks lend first and look for reserves later, as the economist James Galbraith notes: "If anyone believes that reserves are key to lending, they deeply misunderstand what banks do." ${ }^{16}$ He quotes the late economist Hyman Minsky who writes, "Banks don't lend reserves, and they don't need reserves in order to lend. Banks create money by lending. They need a client willing to borrow, a project worth lending to, and collateral to protect against risk. If these are lacking, no amount of reserves will turn the trick. And especially not when the government is willing to pay interest on their reserves: the truest form of welfare, income for doing nothing." 17

\section{How is it relevant that banks create money out of nothing?}

Today, given the nature of money, our entire financial system survives on debt. Debt is how money comes into existence and indebting others is how banks make profit. Thus banks need to produce more and more debt and we need to take on more of it to simply survive; ironically the more debt we take on, the more in turn to survive we need. This pressure of debt-based systemic growth ensures that soon as growth slows, debt rises faster than income and the intensifying debt pressure fuels increasingly desperate attempts to extract more money from somewhere (other people, nature, etc.). Politically, these efforts translate into the very policies encouraging growth that could be said to be collectively destroying the planet itself.

The money-creation process and the imperative of perpetual growth it introduces have today brought about a series of crises and challenges. Below are just some of the features (among others) that are impacting the global economy:

1. Artificial scarcity: ${ }^{18}$ As Bernard Lietar says, "For a bank-debt-based fiat currency system to function at all, scarcity must be artificially and systematically introduced and maintained" $(2001,47)$. We are meant to compete with each other and "rationally" maximise our self-interest in order to operate and survive within the system, thus systematically destroying community ties and communal links. This loss of community occurs because "the current money system obliges us to incur debt collectively, and to compete with others in the community, just to obtain the means to perform exchanges between us" (Lietar, 52). Is it any wonder that the assumption of scarcity is one of the two central axioms of economics, with the second principle being that people naturally seek to maximise their rational self-interest. ${ }^{19}$ On reflection, the two axioms may be interrelated, perhaps even mirror-images. As Eisenstein says, "Greed makes sense in a context of scarcity." ${ }^{20}$ Such greed systemically introduced by the financial system has resulted in an epidemic of mental illness and emotional distress that has gripped much of the modern world. ${ }^{21}$ 
2. Trade distortion: ${ }^{22}$ Another by-product of the money-creation process is its effect on the nature of trade itself. As a result of ever expanding debt, the parameters of trade are distorted. Such distortion is at the level of market prices as supply and demand change through inherent inflation, with property prices a case in point. ${ }^{23}$ Alongside such systemic price distortion is polarisation in wealth accumulation, which in turn leads to monopolistic lines of trade in both the supply and distribution chain. In modern times, nowhere is this more evident than in the Wal-Mart phenomenon..$^{24}$ Another aspect of the distortion of trade is the financialisation of capital itself as an ever increasing money supply entails an eventual cannibalisation of money itself, causing both the trading of capital on the foreign exchange markets and trading on positions on capital in the financial derivatives markets to become the bulk of what is considered trade today. Collectively, today's foreign exchange (forex) and financial derivatives markets dwarf anything else on our planet. In 2010, the volume of foreign exchange transactions reached US\$ four trillion per day, whereas one day's exports or imports of all goods and services in the world amounted to about 2 percent of that figure. It is worth reflecting on this figure, for as Lietar and others go on to say, this means that "98 percent of transactions on these markets are purely speculative" (12). With regard to derivatives, Korten writes: "The total notional amount of over-the-counter derivatives still outstanding totalled an eye-popping \$604.6 trillion in June 2009 , compared with an estimated 2009 gross world product of $\$ 58$ trillion" (118) ${ }^{25}$ In effect, as Lietar and others similarly state, this was over eight times the entire world's annual GDP in same year. Is it any wonder that those writers state that the nature of our money supply has today caused global trade to be akin to a global casino.

3. Inherent booms and bust: The focus of trade on capital itself and its further divestiture into derivatives (options, futures, swaps, etc.) have led us to a situation wherein "waves of credit" as described by Lietar are more like a "financial tsunami" than waves in a calm sea. This volatility and the consequent repercussions create financial instability. According to the London based think tank, International Financial Services London (IFSL): "During the financial crash of 2008, the global total of asset-backed securities issued and sold to investors fell by 79 percent to $\$ 441$ billion, as overleveraged borrowers, banks and investors exited the market. ${ }^{26 "}$ All of this speculation has seemingly come at a cost; as Lietar noted: "According to the IMF, between 1970 and 2010 there were 145 banking crises, 208 monetary crashes and 72 sovereign-debt crises-in other words, a staggering total of 425 systemic crises, an average of more than 10 per year! These crises have hit more than threequarters of the 180 countries that are members of the IMF, many of them being 
hit several times" (12). ${ }^{27}$ These results too are systemic: within the logic of the money creation dynamic, a boom and bust is a reboot mechanism to further concentrate capital.

4. The privatisation and patenting of life itself: Eisenstein writes, "The imperative of perpetual growth implicit in interest is what drives the relentless conversion of life, world, and spirit into money. And yet ... this entire process is considered rational in traditional (neoclassical) economic theory ... [wherein] the very definition of a 'good' is anything exchanged for money" (272). Today, through perpetual growth, forms of natural capital that were hardly recognised have become property, as multilateral agreements such as the International Property Rights (TRIPS ${ }^{28}$ ) aim to force developing countries to extend property rights to indigenous seeds and plant varieties. ${ }^{29}$ Corporate property rights to individual plant genes have already been granted, thereby potentially impacting agricultural practices that two-thirds of the world rely upon for their livelihoods. Likewise, indigenous cultural and local knowledge is increasingly sought to be patented ${ }^{30}$ while viable treatments and cures are denied to the needy on the basis of such patents. ${ }^{31}$ When six corporations own 70 percent of patents on staple food crops, ${ }^{32}$ when the electromagnetic spectrum ${ }^{33}$ sequences of genetic DNA, ${ }^{34}$ and even the earth's capacity to absorb industrial waste are privatised, ${ }^{35}$ something has definitely gone wrong with the world and how we see property. These issues too are linked to the nature of our money supply.

5. Wealth polarisation: As world debt increases because of the nature of the money supply, the corporate interests served by the debt allow for the rich to get richer. Over the last decade, more and more wealth has been concentrated in fewer and fewer hands. When the top three richest individuals in the world own more wealth than the combined GDPs of the 48 poorest countries in the world,${ }^{11}$ when of the world's largest 100 economic entities, 51 are corporations and 49 are countries, ${ }^{36}$ when the world's richest 2 percent own 51 percent of the world's assets while the poorest 50 percent own only 1 percent of its assets, ${ }^{37}$ we have a problem. Such wealth polarisation is systemic to the money creation process, for even in America, purportedly the world's richest nation state, fewer than 7,500 individuals collectively control "almost 75 percent of the nation's industrial (nonfinancial) assets, almost two-thirds of all its banking assets and more than 75 percent of all insurance assets. ${ }^{\prime 38}$ These effects are most manifest in the developing world. Today the average European cow is richer than 75 percent of Africans. ${ }^{39}$ In fact, according to the World Bank, 95 percent of all people in developing countries, which means about 80 percent of all human beings, are living on less than $\$ 10$ a day. Such uneven wealth redistribution is systemic and is tied to the nature of the interest-based money creation process as Dr Margrit Kennedy $\left(1995^{40}\right)$ and others explain. 
6. Ecological destruction: The pressure to perpetually grow and pay off debt is what makes the clearance of rainforest for the growing of monoculture (mostly palm oil) plantations sound economic sense. As Eisenstein writes, "This is how the destruction of a forest to create 100,000 board feet of lumber is, preposterously, counted as an increase in wealth. The forest no longer contributes to soil stability, oxygen production, climate stability, biodiversity protection, and so on, but those losses are not included in the price of a plank of lumber." ${ }^{\prime 4}$ The demands of perpetual growth have also contributed to a gradual exhaustion of the remaining supplies of accessible petroleum, destruction of the world's fisheries and rain forests and an increasing poisoning of the air and water. With every summer getting hotter and every winter getting milder, with a continual incremental increase in the melting of Arctic ice (with some predictions that it will be almost free of ice within the next fifty years) and with the result that the sun is warming our oceans, there is a good deal to be concerned about. With estimates stating that more than a million species worldwide are likely to be driven to extinction by $2050,{ }^{42}$ with half of the world's tropical and temperate forests now gone, with an estimated 90 percent of the large predator fish now gone, with more than one significant scientist saying on record that this may be the last century for the human race, ${ }^{43}$ we have more than a problem! And this problem is linked to the money supply as testified to by a figure as mainstream as the former administrator of the United Nations Development Program, James Gustave Speth, who when writing about impending environmental doom asks what he calls the big question, namely, "How can the operating instructions for the modern world economy be changed so that economic activity both protects and restores the natural world?" 44 Perhaps the best way to answer his question is to look at the roots of the system, the nature of bank money coming into existence itself as interest-based debt.

The above effects and more are indicative of the money creation process and its demand for perpetual economic growth. In fact, today our very societies and the very institutions that engage in commerce are premised on the logic of having to ensure the perpetual growth of capital.

Armor, Hansman and Kraakman state that the five core structural characteristics of the business corporation are: (1) legal personality, (2) limited liability, (3) transferable shares, (4) centralised management under a board structure, and (5) shared ownership by contributors of capital $(2009,7)$. In their paper they state, "These characteristics have strongly complementary qualities for many firms. Together, they make the corporation uniquely attractive for organising productive activity (namely, the maximisation of capital)" (7). 
The logic of maximising capital (at all costs and at the expense of a lot besides) has been described by former Harvard University Business School Professor David Korten as one that destroys life. He writes: "The publicly traded, limited liability corporation is more accurately described as a pool of money with special legal rights and protections dedicated to self-reproduction. The People, including the CEO and directors, can be dismissed without recourse. Only the money, which the corporate officers are legally bound to serve, has rights. In theory it is the shareholders whom management serves, however, since most shares are held in trust by various institutional investors, the real shareholders are generally invisible even to the corporate officers. Management's real focus is on the money, not the shareholders. In effect they are hired by money to nurture its growth and reproduction even at the expense of life." ${ }^{\prime 45}$

The logic of money maximising its own growth even at the expense of life is ultimately the logic of interest-based money and the institutions and regulation it has founded. The problem is that it was within these institutions and regulation that Islamic Finance sought to emerge.

Was that a proper direction to take? By doing so and having Citibank and Goldman Sachs as the prime owners of "Islamic" assets today, have Islamic banks contributed to this process of systemic global destruction, or have they proposed a solution to this process?

\section{What is the role of Islamic banks in the money creation process?}

Saleh Kamel, founder of the Dallah al-Baraka group, in his acceptance speech for the Islamic Development Bank prize in Islamic Banking, 1996, said:

I tell you, truthfully and without pretence ... that we went beyond choosing the "bank" label [in "Islamic Banking"], to the point of adopting its central essence ... Consequently, we failed to give our financial institutions any characteristics beyond simple financial intermediation. This is accomplished through Islamic banks' favourite investment modes that are essentially a hybrid between loans and investment; which hybrid carries most of the characteristics of usurious loans.

For the most part Islamic banks (as currently existing) in their regulation, operational expectations, operational dynamics and organisational structures appear to be entirely the same as commercial banks (Asutay, 2007; Siddiqi, 1999). In practice, the only place they seem ostensibly different is at the transactional level (as they do not extend usurious loans), so it is instructive to analyse the impact this has had, if any, on the money creation process.

First, Islamic banks, just like their conventional counterparts, effectively create bank credit as money out of nothing, i.e., ex nihilo. This they do whenever they enter into a financing transaction. This money in keeping with standard 
bank credit comes into existence on the back of financing documents wherein an accounting entry as a liability to the customer from the Islamic bank appears as digital money in the customer's bank account. Up to this stage the process is remarkably similar to that of conventional banking apart from one difference: when an Islamic bank introduces newly created bank credit as a liability, it does this to finance an asset (or service) and hence could be said to create money that is linked to the asset.

This (money creation linked to an asset) represents a crucial demarcation for some Islamic scholars in Islamic Finance, for while scholars such as Mufti Taqi Usmani accept the inherent expansionary elements of bank credit money through its fractional reserve nature and its subsequent contribution to monetary debasement and inflation (Usmani, 2001), they have not been so forthcoming with regard to Islamic banks. As Mufti Taqi notes, the problem of "artificial money supply ... multiplied without creating real asset in the same quantity" can be solved via Islamic Banking because it is "backed by asset, [therefore] it [money supply] is always matched with corresponding goods and services" (Usmani, 2005, 21-22).

In effect, the claim is that even though Islamic banks create money out of nothing (like their conventional counterparts), they create it relative to the sale/ financing of an asset and hence the credit or money creation by Islamic banks is non-inflationary and will not lead to a debasement of the currency and other related social evils. The logic is that despite Islamic banks' operating on the same reserve basis and money creation paradigm as conventional banks, an increase in the money supply brought by Islamic banks would occur only when an asset is in existence and hence is non-inflationary. With the additional caveat that the Islamic Bank first has to take ownership of the assets to finance it (be it constructive or otherwise) before selling it on, then all the money creation would theoretically be backed by real assets/real economy.

Arguably, what Mufti Taqi and other scholars who support this argument have stated is the equivalent of the 'Real Bills Doctrine' (RBD), a theory that assumes that "inflationary over issue is impossible provided money is issued on loans made to finance real transactions" (Humphrey, 1982, 4). Before analysing the effectiveness of RBD as a theory, it is important to note that by claiming credit expansion in Islamic banks to be non-inflationary and equivalent to RBD, Islamic scholars are essentially making an economic argument. The question as to whether money can actually be created out of nothing as a debt still remains a valid Shariah question to ask, and will be dealt with later.

The RBD theory was initially proposed by bankers themselves, arguably with spurious motives. They sought to justify the credit creation by commercial banks on the basis that such new credit was going towards productive activities, 
and hence, they argued, it wasn't inflationary. It is important to mention that this theory has generally been held in ill repute and is considered discredited by economists since the 1950s, mainly on the basis that all monetary creation from commercial banking is inherently inflationary due to the introduction of a future greater debt, namely, the interest. It is the interest that drives forward an inflation spiral due to the fact that the amount of money being paid back to the banks is always greater than the current money supply. The only way such a spiral can be stopped would be for the money created genuinely to go towards productive purposes with no cost of capital. Let us see how Islamic banks fare in this regard.

In the context of Islamic Banking (as currently practiced), there are three key issues about the credit creation process that show a parallel to that of commercial banks:

1. The asset ownership Islamic banks assume is incidental. Credit creation on the back of a "sale" for Islamic banks is a means to facilitate the creation of debt money. This often means there is a single asset with multiple exchanges, as in the case of Banking Tawarruq. Likewise, when a piece of land, a vehicle, or machinery, etc., is "purchased" many times over simply for seeking the services of a financial intermediary, each step involves the creation of credit for the same asset or commodity. This means that such a sale is not a productive one but an incidental one to facilitate debt. Issuing newly created money to an existing stock of goods is not the same as producing more goods as such bank credit does not fund production but instead creates nothing but credit expansion, entirely similar to its conventional counterpart.

2. Credit comes into existence with a corresponding cost of credit. When Islamic banks create credit on the back of a sale, this newly created money has the banks crediting themselves in return for the corresponding amount of money plus the profit (with the profit being inevitably benchmarked to the prevalent interest rate, namely, the cost of credit). What this means is that by adopting the paradigm of money only coming into existence as interestbearing debt, Islamic banks though seeking to justify their profits (as linked to sales), continually perpetuate the problem of there being insufficient money in existence to repay the debts created by the banking system itself. This means that Islamic banks continue the perpetual growth paradigm with the same logic and ill effects created by the conventional commercial banks as discussed earlier.

3. Credit creation in Islamic banks causes an inflationary spiral. As Islamic banks continually benchmark their profit differential to LIBOR, EBOR, etc., they produce and perpetuate a continual rather than merely a one-time rise in money and prices. The Interbank interest-based benchmark is designed to be always profitable when compared to production costs (so as to stimulate borrowing), but the increased cycle of borrowing needs more lending, greater 
monetary expansion, and still higher prices, and so continues ad infinitum in a cumulative inflationary spiral. Interest always leads to inflation unless more and more goods are bought and sold. By perpetuating the same differential between the money to be paid back and that existing in the economy, Islamic banks place the same pressures of inflation, increased privatisation, and wealth polarisation as those of normal commercial banks by their credit expansion.

In short, economically speaking, there is very little difference between the effects caused by the credit expansion of commercial banks and those caused by Islamic banks. If one bears in mind that such credit expansion in general (as discussed earlier) can be linked to artificial scarcity, trade distortion, inherent booms and bust, wealth polarisation and ecological destruction, this is distressing indeed.

It is sad that Islamic banks have yet to review their essential nature in this regard, that instead of consistently operating within the same system as commercial banks, i.e. by maintaining Statutory Liquidity and Cash Reserve Requirements, they do not seek to charter their own institutions and regulation. For now, it is empirically evident that Islamic banks function economically the same as conventional banks, as the data on their balance sheets cannot be differentiated from those of their conventional counterparts. In a report to State Bank of Pakistan, a consolidated balance sheet of an Islamic bank showed that the total cash was Rs. 15.2 billion vs. total deposits of Rs. 83.7 billion and the total liabilities of Rs. 102.3 billion (Ahmad \& Baloch, 2007). What this showed was that Islamic banks expand credit-based money and generate a money multiplier effect, exactly like their conventional counterparts. If this is the case, then Islamic banks, far from removing the evils of conventional banking, are actually perpetuating the debt-based system. This would be a far cry from what Mufti Taqi and other scholars perceived Islamic financing to be when he said, "The original concept of Islamic financing is undoubtedly in favour of equity participation rather than creation of debts, because it is only equity participation that brings an equitable and balanced distribution of wealth in the society. Debtridden economy, on the other hand, tends to concentrate wealth in the hands of the rich, and creates a bubble economy which fuels inflation and brings many other social and economic evils" (Usmani, 2008).

\section{What about the Shariah permissibility of the money creation process itself?}

The aforementioned discussion was focused on the economic effects of Islamic banks and the result of their continuing with the paradigm of money creation of their conventional counterparts. Although money creation in Islamic banks is coupled with the sale of an asset or provision of a service, the analysis shows that Islamic banks currently perpetuate many of the social, environmental and 
economic problems of their conventional equivalents, due to the fact that such money creation is embedded within the dynamics of an interest- based paradigm. Although this fact alone may necessitate significant Shariah consideration, questions still remain as to the issue of money creation from nothing as a debt. Thus it would be instructive to see prevalent Islamic opinion on this matter.

When looking at the issue of money creation and fractional reserve banking, the Islamic Fiqh Academy (IFA) in its Resolution No.86/3/95 stated that "Call deposits (current accounts) whether at Islamic banks or interest-based banks, are considered as loans, from a Shariah perspective, since the bank taking delivery of these deposits is answerable for their safety and bound Shariah wise to returning them on call. The ruling applicable to the loan is no way affected by the Bank's [the borrowers'] solvency or otherwise." ${ }^{\prime 46}$

Hence, the logical argument proposed by IFA was that just as it is seemingly legally permissible in Islamic law for a borrower to further lend, invest or otherwise utilise borrowed money as long as he remains obligated to the original lender in an on-account format (lit: Tahta al Hisaab), such that he is able to repay on demand, it should similarly likewise be fine for financial institutions to operate on such a basis, provided they remain similarly obligated. The argument supposedly continues that just as the measures a borrower takes to mitigate the possibility of his not being able to pay on demand are subject to his ability, with no stipulation existing in Islamic Law concerning the degree of solvency needed to be maintained, similar flexibility should be extended to financial institutions. Hence, the argument of the impossibility of banks actually meeting every lender's demand because of the money simply not existing is not deemed to carry weight, as the support provided by the "lender of last resort", namely the Central Bank, is seen as sufficient to offset such a risk.

Though it may be argued that theoretically this resolution makes sense, others may state that it is reductionist and legally formalistic in that there are still significant Shariah concerns that are inadequately answered. Some of these concerns are the following:

1. What the IFA statement seems to ignore in this resolution is that commercial bank money is not money in a traditional Fiqhi sense at all, but is instead promissory debt that uniquely functions as money within an economy founded on such promissory debt. Does the Shariah have any precedent for sanctioning a promissory debt, effectively as an IOU, to function as money?

2. What is the Shariah justification for the creation of purchasing power out of nothing which then allows for the ownership transfer of assets in an economy? This is especially important given that ownership principles in Islam are associated with legitimate risks and work. 
3. Given that the money creation process proliferates debt and causes wealth polarisation, trade distortion and ecological destruction, are Islamic banks allowed to perpetuate the current paradigm?

4. Can money created by a bank as a liability be used to fund investment ventures, given that traditionally debt cannot be used to finance investment ventures such as Musharaka and Mudaraba?

5. Is it permissible in Islam for the money creation process to be effectively privatised for the benefits of a portion of the financial elite, as is the case with commercial banking?

\section{Conclusion}

In recent times the pressure group Positive Money ${ }^{47}$ in the UK has campaigned against what it considers the undemocratic nature of the banking system, as its founder, Ben Dyson, states: 'Simply 'getting banks lending again' won't help when the public are already saddled under a mountain of debt. What we need is more money, not more debt. This is impossible while all money is created by banks when people go into debt... The power to create money is far too dangerous to leave in the hands of the banks who caused the crisis. Taking this power away from them is our best hope of both ending the current crisis, and preventing the next one." ${ }^{\prime 4}$

For the purposes of this paper, we hoped to illustrate that the privatisation of the world's money supply and its creation, for the commercial gains of an increasingly financially privileged minority ${ }^{49}$ is an outcome of the story of interest and its central institution, the commercial bank. Islamic banks by co-opting this institution and seeking to "Islamicise" it may have gone down a wrong route (in regard to their originally stated motives).

What may be better and more just is for Islamic banks to join the various movements in the world that are seeking to amend the underlying structures of banks themselves, thereby seeking to bring forth a new narrative with regard to commerce and money, one that is more just and equitable. To many, the need for a new narrative has become an imperative as we are currently at the threshold of a series of crises caused by the financial system and the perpetual growth of the money it requires to survive. We just can't continue growing; the growth has long become oppressive. Is it merely a coincidence that among the meanings of Riba is "oppressive growth"?

Today, we have reached an impasse in our ability to grow. We have reached an impasse in our ability to convert nature into money. As Eisenstein says, "There is little more we can convert. Technological progress and refinements to industrial methods will not help us take more fish from the seas - the fish are mostly gone. It will not help us increase the timber harvest - the forests are already stressed to capacity. It will not allow us to pump more oil - the reserves are drying up. 
We cannot expand the service sector - there are hardly any things we do for each other that we don't pay for already. There is no more room for economic growth as we have known it; that is, no more room for the conversion of life and the world into money." 50

Crisis heralds a chance for a new narrative, one previously inconceivable but presently feasible. As we continue to scramble towards applying new and not so new fixes to further prop up this interest-based system at an ever greater cost to alleviate the very problems caused by it, hope emerges in initiatives that challenge the structural dynamics of interest and the institutions it brings about. "Bailout" packages raised from public money given to the very banks that have caused the crisis have run their course. In their place is an emerging mass movement determined to reclaim the freedom of people for themselves. Islamic banks too need to make a decision in this regard. They need to answer the perennial question, where then are you headed? with regard to the money creation process.

As things stand, Islamic banks allow for Muslims and others who want to be a part of this collapsing, oppressive system to partake "Islamically", but with this system itself headed towards imminent collapse, for how long can this continue? Would it not be better for Islamic banks to redesign themselves into community oriented institutions, for them to partake in and contribute to the movements of ecological awareness, localism, green design, community currencies, ecology-based economics, gift economics, negative interest currencies, public co-operative interest-free banking, community land trusts, gold dinar, and open community markets that are all currently seeking to challenge the hegemonic nature of the interest-based financial system. Would it not be better for them to aid and abet $\mathrm{B} 2 \mathrm{~B}$ and $\mathrm{p} 2 \mathrm{P}$ financing schemes which reconnect people to people and form communities, at the expense of the current interest-based model that destroys community in favour of anonymous, impersonal financial institutions which have been described as psychopathic in their relentless pursuit of profit at all costs? ? $^{51}$

Is it not time that Islamic finance itself undergo a reformation from within, from practitioners and academics ${ }^{52}$ who expect that the word Islamic entails a holistic analysis (by which they mean an analysis of structures, means and ends, direction, etc.), and not a reductionist one (myopically focused on transactions divorced from context)? Is it not time to rise above the slumber that has entered Islamic banking from a lack of direction? Is it not time to move beyond interest and the institutions and social settings it has brought about? Is it not time to propose a new mechanism for the supply of money, to create a supportive financial environment that decreases our reliance on debt and increases our sense of community?

Is it not time to save the world before it's too late? So "where then are you going?" [Qur'an 81:26]. 


\section{References}

Armor, J., H. Hansman, and K. Kraakman. The Essential Elements of Corporate Law. Oxford: University of Oxford, Legal Studies Research Paper No.20, 2009.

Asutay, M. "Conceptualisation of the Second Best Solution in Overcoming the Social Failure of Islamic Finance: Examining the Overpowering of Homoislamicus by Homoeconomicus". IIUM Journal of Economics and Management, 15, no. 2 (2007), 167-176.

Bakan, J., The Corporation: The Pathological Pursuit of Profit and Power. Free Press, 2005.

De Soto, J.H. Money, Bank Credit and Economic Cycles. Ludwig von Mises Institute, 2006, http://mises. org/books/desoto.pdf

Douthwaite, R. The Ecology of Money (Schumacher Briefings). Green Books, 2000.

Douthwaite, R. Short Circuit: A Practical New Approach to Building More Self-Reliant Communities. Green Books, 1996.

Diwany, T.E. The Problem with Interest. Kreatoc Ltd, 2003.

Eisenstein, C. The Ascent of Humanity. Panenthea Productions, 2007.

Eisenstein, C. Sacred Economics: Money, Gift, and Society in the Age of Transition. Evolver Editions, 2011.

Graeber, D. Debt: The First 5,000 Years. First Melville House Printing, 2011.

Humphrey, T. "The Real Bills Doctrine". Economic Review (Federal Reserve Bank of Richmond), 1982, 3-13.

Kennedy, M. Interest and Inflation Free Money. Seva International, 1995. http://kennedybibliothek.info/data/ bibo/media/GeldbuchEnglisch.pdf

Kennedy, M. Occupy Money: Creating an Economy Where Everybody Wins. New Society Publishers, 2012.

Korten. D.C. Agenda for a New Economy: From Phantom Wealth to Real Wealth. Berrett-Koehler Publishers, 2010.

Korten. D.C. When Corporations Rule the World. Berrett-Koehler Publishers, 2001.

Lietaer, B. The Future of Money: Beyond Greed and Scarcity. London: Random House, 2001.

Rowbotham, M. The Grip of Death: A Study of Modern Money, Debt Slavery and Destructive Economics. The Cromwell Press, 1998.

Ryan-Collins, J., R. Werner, and T. Greenham. Where does Money come from? A guide to the UK Monetary and Banking System. NEF (the New Economics Foundation), 2011.

Siddiqi, M.N. Islamic Finance and Beyond - Premises and Promises of Islamic Economics. Cambridge, MA: Harvard University, 2011, 49-53.

Usmani, M.M.T. The Text of the Historic Judgment on Interest. 2001. http://www.albalagh.net/Islamic economics /riba_judgement.shtml

\section{Notes}

* Yusuf Jha is a Chartered Sharia Auditor and Advisor formally certified by AAOIFI (Accounting and Auditing Organization for Islamic Financial Institutions) and currently works for Abu Dhabi Islamic Bank in the GCC as a Manager in charge for Sharia Consultation and Documentation. Alongside his daily tasks of consultancy and auditing he often presents products and ideas to his Sharia Board. Prior to his current role, he worked for BMB Islamic and Dar Al Istithmar as an Islamic Finance consultant in London. A graduate from the University of Birmingham, UK, he also worked as a Corporate Trainer and Systems Analyst at Accenture. He has received formal training in Islamic wills and inheritance tax and investment planning in the UK; and is qualified as a UK Chartered Independent Financial Advisor (IFA).

1. The fragility of the global financial system is illustrated by impending hyperinflation, currency collapse, and depression waiting for the day when the American dollar can no longer be sustained.

2. Peak Oil and the dependency of all aspects of our economic infrastructure and food supply on fossil fuels are a significant challenge when one considers the argument that no conventionally recognised alternative energy source can possibly be expected to replace oil and gas any time soon.

3. Recent times have seen an epidemic rise of autoimmune diseases, heavy metal poisoning and electromagnetic, chemical, and genetic pollution. These factors, aligned with the degeneration of the modern diet and the toxicity and impotence of most pharmaceutical drugs are a significant cause for concern.

4. Climate change, global warming, desertification, coral bleaching, tree death, topsoil erosion, habitat destruction, irreversible loss of biodiversity, toxic and radioactive waste, PCBs in every living cell, 
swaths of disappearing rainforests, dead rivers, lakes and seas, increasing slag heaps and quarry pits all point to the fact that the planet the next generation will inherit will be very different to one we currently live on. This has caused environmentalists like Bill McKibben to coin a new name for the planet to come: Eaarth $<\mathrm{http}: / /$ www.billmckibben.com/eaarth/factsandfigures.html>.

5. Sir Mervyn King, Speech to the South Wales Chamber of Commerce at The Millennium Centre, Cardiff, 23 October 2012.

6. Martin Wolf, Financial Times, 9 November 2010.

7. Adair Turner, Chairman of the FSA, Speech: "Credit Creation and Social Optimality", September 2011.

8. C. Eisenstein, "We can't grow ourselves out of debt, no matter what the Federal Reserve does", The Guardian, 3 September 2012, <http://www.guardian.co.uk/commentisfree/2012/sep/03/debt-federalreserve-fixation-on-growth>.

9. Bank of England Paper: Interpreting movements in broad money, 377.

10. Paul Tucker, Deputy Governor for Financial Stability, Bank of England. Speech: "Shadow Banking: Thoughts for a possible policy agenda".

11. For more quotes along these lines, see $<$ http://www.positivemoney.org/how-banks-create-money/proofthat-banks-create-money/>.

12. See speech (given in December, 2007) by Paul Tucker, Executive Director, Monetary Policy Committee, Bank of England, <http://www.bankofengland.co.uk/publications/Documents/speeches/2007/ speech331.pdf $>$.

13. The secretariat of the Basel Committee of Banking Supervision is located at the Bank of International Bank of Settlements (BIS) in Basel, Switzerland. Surprisingly, the committee is a private body of central banks and regulators, many of whom may have links to the very banks they seek to regulate.

14. These are effectively interbank investments that due to their perpetual and subordinated nature are considered tier 1 capital for regulatory purposes, $<\mathrm{http}$ ://www.allenovery.com/SiteCollectionDocuments/ Tax Treatment of Additional Tier 1 Capital under Basel III.pdf >.

15. Basel III is the latest in line of global regulatory standards on capital adequacy ratios following on from Basel I and Basel II, both of which were easily circumvented and not effective in limiting banks, $<$ http:// www.bis.org/bcbs/basel3.htm>.

16. <www.guardian.co.uk/commentisfree/2012/sep/20/quantitative-easing-not-magic-central-banks >

17. Ibid.

18. This fits into the paradigm of the "Devilish touch" in the definitive verse against interest [Qu'ran, $2: 268]$ as causing those affected to feel "threatened with poverty and urged to immorality", being an apt definition for the phenomenon of artificial scarcity.

19. Eisenstein, Sacred Economics: Chapter 2, "The Illusion of Scarcity," 2011.

20. Ibid.

21. Renowned psychologist Oliver James, in his bestselling book Affluenza, introduces what he refers to as a modern psychological virus primarily sweeping through the English speaking world since the 1970s. The symptoms of those suffering from this "virus", he lists as being obsessive, with envious, greeddriven tendencies, with twice as much of a likelihood to be suffering from anxiety, depression and other addictions than people in other nations. In his subsequent book entitled The Selfish Capitalist, he argues that the epidemic of mental illness and emotional distress that has primarily gripped English speaking nations is primarily due to policies that have aided the usurious world, policies he refers to as "selfish capitalism". As the Qu'ran says: "Those who consume interest cannot stand except as one who stands being touched by a Devilish touch into insanity” [Qu'ran, 2:275].

22. As the Qu'ran says: "They say, 'Trade is [just] like interest.' But God has permitted trade and forbidden interest."

23. Since the beginning of the 1960s the average house price in the UK has increased by 273 percent in real terms (i.e., even after allowing for retail price inflation). As indicated by the UK Positive Money website, this price distortion reflects more the banks' continual need to lend and the subsequent capacity to borrow than any market dynamics in and of itself $<$ http://www.positivemoney.org.uk/consequences/ house-prices/>.

24. See $<$ http://www.neweconomics.org/publications/will-wal-mart-eat-britain>.Wal-Mart ranks as the $33^{\text {rd }}$ largest economy in the world, having greater purchasing power than most nations. It was China's fifth largest trading partner, ahead of the UK, Russia and Germany. The company captures one of 
every five dollars spent on food, sells more clothing, furniture, toys, jewellery, music CDs, DVDs, magazines, books than any other retailer and accounts for nearly one-third of the entire US market for many household staples. As a result its power extends all the way from farms and factory floors to publishing houses all across the globe. No other company on earth exerts as much power and control over how and where goods are produced. The domination of multinational corporations like Wal-Mart can be directly attributable to an interest-based paradigm that gives power and wealth to those that already have the most.

25. "Bank for International Settlements", table 19 (see chap.7, n.5) in Korten, 290.

26. <www.ifsl.org.uk>

27. $<$ http://www.clubofrome.org/cms/wp-content/uploads/2012/05/Money-and-Sustainability-the-missinglink-Executive-Summary.pdf $>$

28. <http://www.wto.org/english/tratop_e/trips_e/trips_e.htm>

29. See $<\mathrm{http}: / /$ www.inmotionmagazine.com/global/vshiva4_int.html $>$ wherein the environmental activist Vandana Shiva writes: "If you want to have one tool for imperialistic control, it's patent law under the WTO agreement .... With the broadening of patents to life forms, patents do not just regulate technology; they regulate life."

30. See attempts to patent the Neem Tree, $<$ http://wwwl.american.edu/ted/neemtree.htm $\geq$.

31. See the story of the man who stood up to the plaintiffs of 39 pharmaceutical corporations who sued the South African government for its effort to import and produce cheaper generic HIV/AIDS drugs, which the corporations alleged violates their patent rights under international trade law $<$ http://www.time.com/ time/nation/article/0,8599,106995,00.html>.

32. <http://www.actionaid.org.uk/_content/documents/trips2_3132004_122755.pdf $>$

33. <http://www.brookings.edu/ /media/research/files/papers/2007/2/28useconomics $\% 20$ crandall $\% 20$ opp08/pb_deregulation_crandall>

34. <http://www.policymic.com/articles/3633/should-dna-data-belong-to-private-companies-the-geneticalliance-fights-for-open-access $>$

35. "Pollution credits and similar schemes seek to convert the earth's absorptive capacity into property." (Eisenstein)

36. <http://www.corporations.org/system/top100.html>

37. See James B. Davies, ed., Personal Wealth from a Global Perspective (Oxford: Oxford University Press, 2008).

38. As noted by political scientist Thomas Dye in Who's Running America.

39. In 2005, World Bank chief economist Nicholas Stern estimated that on average each European cow receives $\$ 2.50$ a day in government livestock and dairy subsidies while 75 percent of African people live on less than $\$ 2$ dollars a day.

40. Dr Margrit Kennedy states that interest structurally redistributes wealth from the large majority to a small minority. For further details see $<$ http://www.zoupic.com/tag/wealth-distribution/>.

41. <http://charleseisenstein.net/why-rio-20-failed/> (accessed 17 November 2012).

42. See Al Gore, An Inconvenient Truth.

43. Sir Martin Rees, arguably Britain's most distinguished theoretical astrophysicist, holds that there is a 50:50 estimate that this will be humanity's last century, <http://www.amazon.co.uk/exec/obidos/ ASIN/0434008095/guardianunlim-21>. Also see James Lovelock, originator of the Gaia theory, who expects "about $80 \%$ " of the world's population to be wiped out by $2100,<$ http://www.guardian.co.uk/ theguardian $/ 2008 / \mathrm{mar} / 01 /$ scienceofclimatechange.climatechange $>$.

44. James G. Speth, The Bridge at the Edge of the World: Capitalism, the Environment, and Crossing from Crisis to Sustainability (2008), <http://www.amazon.com/The-Bridge-Edge-World-Sustainability/ $\mathrm{dp} / 0300136110>$.

45. <http://livingeconomiesforum.org/ii-pathology>. David Korten is one of the foremost authors against corporations and globalisation; a former Harvard Business School professor and a development economist, he is a strong advocate for a people-driven economy, one that is for Main street as opposed to Wall Street, one that in his words puts real wealth over phantom wealth (2010).

46. "Resolution and Recommendations of the Council of the Islamic Fiqh Academy (1985-2000)", IRTI.

47. Positive Money, $<\mathrm{http}: / /$ www.positivemoney.org.uk $>$

48. <http://www.guardian.co.uk/commentisfree/2011/nov/15/money-privatised-stealth> (accessed 
November 2012).

49. Ibid.

50. Ibid.

51. See Joel Bakan, The Corporation: The Pathological Pursuit of Profit and Power, and its related website: www.thecorporation.com. Bakan is a professor of law at the University of British Columbia.

52. For example, see the work of Dr Adi Setia in Malaysia, who has been striving to set up a local community finance co-operative in Kuala Lumpur in place of Islamic banking, along these lines:

a. Islamic Community Investment Corporation, focusing solely on Mudaraba and Musharaka.

b. Islamic Community Depository Corporation, focusing solely on Wadi'a providing safety deposit, storing and warehousing services for a fee.

c. Islamic Community Payment (or Clearing) System, focusing on hawalah and payment clearing and netting off services, that can offer debit cards and checking services.

d. A waqf based takaful system to spread local community risk.

For more information on Dr Adi's ideas, see <http://www.uaekhutba.com/images/stories/docs/IGE. pdf $>$. Also see the inspiring work of Dr Amjad Saqib and his organisation Akhuwat in Pakistan (http:// www.akhuwat.org.pk/) and their efforts in eradicating poverty using Prophetic principles to create the world's first fully interest-free microfinance institution. See an interview with Akhuwat: $<$ http:// www.ethicainstitute.com/ethica_interviews_akhuwat_the_worlds_first_completely_interest_free_ microfinance_program.aspx $>$. 